\title{
EKSTRAKSI DAN KARAKTERISASI GLUKOMANAN DARI TEPUNG BIJI SALAK (Salacca edulis Reinw.)
}

\section{[EXTRACTION AND CHARACTERIZATION OF GLUCOMANNAN FROM SALAK (Salacca edulis Reinw.) SEED FLOURS]}

\author{
Faradisa Anindita ${ }^{1^{\star}}$, Syaiful Bahri ${ }^{1)}$, Jaya Hardi ${ }^{1}{ }^{\text {) }}$ \\ 1) Jurusan Kimia, Fakultas MIPA Universitas Tadulako, Palu \\ Diterima 13 Desember 2015, Disetujui 2 Februari 2016
}

\begin{abstract}
This research aims to determine the shaking time and ratio of salak seed flour : anti-solvent isopropyl alcohol to produce glucomannan extract with high yield and high quality. Glucomannan extraction process from salak seed flour is done by aquadest solvent at temperature of $95{ }^{\circ} \mathrm{C}$ with shaking speed of $700 \mathrm{rpm}$ for $30,60,90,120,150$, and 180 minutes. Glucomannan precipitate was gained with antisolvent isopropyl alcohol 95\% with salak seed flour : anti-solvent ratio is 1:9, 1:11, 1:13, 1:15, and 1:17 $(\mathrm{w} / \mathrm{v})$. Then research using Completely Randomized Design (CRD) at the level of $95 \%$. The results showed the best extraction time was obtained at shaking time of 120 minutes with yield of $21.47 \%$ and the best ratio of salak seed flour : isopropyl alcohol is 1: $17(\mathrm{w} / \mathrm{v})$ with yield of $40.19 \%$. Characteristics of glucomannan is a water content of $11.18 \%$, ash content of $1.2 \%$, and the molecular weight $2.057 \times 10^{4} \mathrm{~g} / \mathrm{mol}$.
\end{abstract}

Keywords : salak seed flour, shaking time, glucomannan.

\begin{abstract}
ABSTRAK
Penelitian ini bertujuan untuk mengetahui waktu pengocokkan dan rasio tepung biji salak : anti-solvent isopropil alkohol terbaik dalam menghasilkan ekstrak glukomanan dengan rendemen dan mutu tinggi. Proses ekstraksi glukomanan dari tepung biji salak dilakukan dengan pelarut aquades pada suhu $95^{\circ} \mathrm{C}$ dengan kecepatan pengocokan $700 \mathrm{rpm}$ selama 30,60, 90, 120, 150, dan 180 menit. Endapan glukomanan diperoleh dengan menggunakan anti-solvent isopropil alkohol $95 \%$ dengan perbandingan tepung biji salak : anti-solvent 1:9, 1:11, 1:13, 1:15, dan 1:17 (b/v). Penelitian menggunakan Rancangan Acak Lengkap (RAL) pada taraf kepercayaan 95\%. Hasil penelitian menunjukkan waktu pengocokan terbaik diperoleh pada 120 menit dengan rendemen glukomanan 21,47\% dan rasio tepung biji salak : anti-solvent isopropil alkohol terbaik yaitu $1: 17(\mathrm{~b} / \mathrm{v})$ dengan rendemen glukomanan 40,19\%. Hasil karakterisasi terhadap glukomanan adalah kadar air 11,18\%, kadar abu $1,2 \%$, dan berat molekul $2,057 \times 10^{4} \mathrm{~g} / \mathrm{mol}$.
\end{abstract}

Kata kunci : tepung biji salak, waktu pengocokan, glukomanan. 


\section{LATAR BELAKANG}

Salak merupakan salah satu buah lokal yang ditemukan hampir disetiap daerah di Indonesia. Bagian buah salak yang dapat dikonsumsi hanya sekitar 56$65 \%$, sehingga menghasilkan limbah 35$44 \%$. Salah satu bagian limbah salak yang belum banyak dimanfaatkan adalah bagian biji, karena mempunyai tekstur yang keras dan tidak mudah hancur, sehingga pengolahan biji salak cukup sulit (Supriyadi dkk., 2002). Biji salak memiliki kandungan kimia utama berupa karbohidrat terdiri dari $28,98 \%$ selulosa dan $59,37 \%$ hemiselulosa berupa glukomanan, serta dalam satu gram biji salak mengandung 0,1637 gram mannosa dan 0,0089 gram glukosa (Nugroho, 2014).

Glukomanan merupakan senyawa polisakarida yang tersusun dari Dmannosa \pm 67 persen dan D-glukosa \pm 33 persen serta memiliki sifat antara selulosa dan galaktomanan, sehingga dapat mengkristal dan membentuk struktur serat halus. Pemanfaatan glukomanan telah menyebar pada beberapa industri diantaranya industri edibel film, bahan perekat, isolasi, industri makanan, cat, payung, kosmetik, obatobatan, dan lain-lain (Koswara, 2009). Pada bidang kesehatan, glukomanan digunakan untuk mencegah penyakit jantung dengan menurunkan kolesterol dan mengurangi respon glukemik (Singh dan Shelley, 2007).
Beberapa penelitian telah dilakukan untuk mendapatkan glukomanan dari beberapa tumbuhan seperti iles-iles (Amorphophallus. Sp) (Koswara, 2009), bungkil inti sawit (Yopi, dkk., 2006), dan lidah buaya (Retnowati dan Kumoro, 2012). Rendemen glukomanan yang diperoleh dari tumbuhan tersebut dipengaruhi oleh varietas, metode ekstraksi, jenis anti-solvent/pengendap (Retnowati dan Kumoro, 2014), suhu (Rohimi, F dan Ninghidayati, S, 2013), perbandingan pelarut dan massa padatan, waktu ekstraksi (Fadilah, dkk, 2009), serta rasio anti-solvent dan massa padatan (Saputro dkk., 2014).

Beberapa penelitian tentang waktu ekstraksi glukomanan dilaporkan bahwa waktu ekstraksi terbaik pada glukomanan dari umbi iles-iles yaitu selama 3 jam (Fadilah, dkk, 2009). Selain itu Istianah, dkk. (2012) melaporkan bahwa waktu ekstraksi terbaik pada glukomanan dari lidah buaya yaitu selama 2 jam. Berdasarkan penelitian tersebut, maka perlu dilakukan kajian untuk mengetahui kondisi terbaik pada ekstraksi glukomanan dari tepung biji salak.

\section{METODE PENELITIAN}

\section{Bahan dan Peralatan}

Bahan dasar yang digunakan dalam penelitian ini adalah biji salak. Bahan bahan lainnya: aquadest, isopropil alkohol 95\%, etanol 95\%, $\mathrm{HCl} 2 \%, \mathrm{NaOH} 10 \%$, arang aktif, fenilhidrazin hidroklorida, dan Na-asetat. 
Peralatan yang digunakan : blender, gelas kimia, hot plate WiseStir MSH 20-D, homogenizer, kertas saring, oven Memmert, neraca analitik Adventure TM Ohaus, desikator, cawan porselen, tanur Nabertherm gmBh, spektrofotometer FTIR, sentrifugasi, viscometer ostwald dan alat-alat gelas lainnya.

\section{Rancangan Penelitian}

Penelitian ini menggunakan Rancangan Acak Lengkap (RAL) dengan variabel bebas waktu pengocokan dan rasio tepung biji salak terhadap antisolvent isopropil alkohol 95\% dengan variabel tetap rendemen glukomanan. Variabel waktu pengocokan terdiri dari 6 taraf $(30,60,90,120,150$, dan 180 menit), sedangkan variabel rasio tepung biji salak : anti-solvent isopropil alkohol 95\% terdiri dari 5 taraf $(1: 9,1: 11,1: 13$, $1: 15$, dan $1: 17(\mathrm{~b} / \mathrm{v}))$ dan masing-masing dilakukan secara duplo.

\section{Prosedur Penelitian}

\section{Preparasi Sampel}

Biji salak dipisahkan dari kulit dan dagingnya, kemudian biji dicuci dengan air mengalir hingga bersih. Setelah itu, biji dipecah dan digiling kemudian dikeringkan dengan menggunakan sinar matahari. Serbuk biji salak kering diblender dan diayak dengan ayakan 60 mesh hingga diperoleh tepung biji salak. Tepung biji salak selanjutnya ditentukan kadar glukomanannya dengan menggunakan metode pembentukan kristal phenylhidrazin (Ohtsuki, 1968).

\section{Penentuan Waktu Pengocokan Pada Ekstraksi Glukomanan}

Ekstraksi

glukomanan

menggunakan metode Whistler dan Richards (Syaefullah, 1990). Sebanyak $20 \mathrm{~g}$ tepung biji salak dicampurkan sedikit demi sedikit pada aquades dengan perbandingan 1:30 (b/v) sambil diaduk pada kecepatan $700 \mathrm{rpm}$, suhu $95{ }^{\circ} \mathrm{C}$ selama waktu tertentu (sesuai perlakuan). Filtrat campuran diperoleh setelah proses sentrifugasi pada kecepatan 3000 rpm selama 15 menit yang selanjutnya dipekatkan hingga setengah volume awal. Glukomanan yang terkandung dalam filtrat diendapkan menggunakan anti-solvent isopropil alkohol $95 \%$ dengan perbandingan 1:13 (b/v). Glukomanan yang terbentuk dicuci dengan etanol 95\% dan dikerikan untuk memperoleh serbuk glukomanan.

\section{Penentuan Rasio Tepung Biji Salak terhadap Anti-Solvent Isopropil Alkohol pada Ekstraksi Glukomanan}

Sebanyak $20 \mathrm{~g}$ tepung biji salak dicampurkan sedikit demi sedikit pada aquades dengan perbandingan 1:30 (b/v) sambil diaduk pada kecepatan 700 rpm, suhu $95{ }^{\circ} \mathrm{C}$ selama 120 menit. Filtrat campuran diperoleh setelah proses sentrifugasi pada kecepatan 3000 rpm selama 15 menit yang selanjutnya dipekatkan hingga setengah volume awal. Glukomanan yang terkandung dalam filtrat diendapkan menggunakan anti-solvent isopropil alkohol $95 \%$ dengan perbandingan sesuai perlakuan. 
Glukomanan yang terbentuk dicuci dengan etanol 95\% dan dikerikan untuk memperoleh serbuk glukomanan.

\section{HASIL DAN PEMBAHASAN}

\section{Kadar Glukomanan Biji Salak}

Glukomanan merupakan komponen karbohidrat yang paling banyak dalam tepung biji salak. Pengukuran kadar glukomanan dilakukan dengan metode phenylhidrazin. Prinsip uji phenylhidrazine adalah berdasakan gugus karbonil dari aldosa dan ketosa yang bereaksi dengan adanya penambahan larutan phenylhidrazine akan membetuk senyawa osazon berwarna kuning jingga. Mekanisme pembentukan osazon terjadi karena gugus aldehid ataupun keton dari karbohidrat berikatan dengan phenilhidrazine. Reaksi antar senyawa tersebut merupakan reaksi oksidasi reduksi, dimana atom $\mathrm{C}$ nomor satu dan dua dari aldosa atau ketosa mengalami reaksi. Fruktosa, glukosa, dan manosa menunjukan osazon yang sama (Sudarmadji, 1989). Berdasarkan metode tersebut diperoleh kadar glukomanan pada tepung biji salak sebesar $72,83 \%$.

Widjanarko dan Megawati (2015) melaporakan kadar glukomanan pada tepung konjak adalah $63,49 \%$ dengan metode gravimetri. Selain itu, Wigoeno (2013) melakukan analisis glukomanan pada umbi porang (Amorphopallu muelleri Blume) dengan metode phenylhidrazin diperoleh rata-rata kadar glukomanan 50,84 - 70,70\%. Akbar, dkk., (2013) juga mengukur kadar glukomanan pada tepung konjak pada tanaman iles-iles dengan metode phenylhidrazin diperoleh kadar glukomanan sebesar $30,56 \%$. Ini berarti glukomanan pada biji salak jauh lebih tinggi jika dibandingkan dengan umbi konjak atau porang yang selama ini menjadi sumber glukomanan. Oleh karena itu, biji salak memiliki potensi sebagai sumber glukomanan.

Tinggi rendahnya kadar glukomanan pada tumbuhan dipengaruhi oleh kadar pati, kadar serat, dan kadar oksalat. Sebagaimana yang dikemukakan oleh Faridah dkk., (2012) bahwa peningkatan kadar glukomanan sejalan dengan menurunnya komponen non-glukomanan lainnya, seperti oksalat, protein,lemak, abu, dan pati.

\section{Waktu Pengocokan Terseleksi pada Ekstraksi Glukomanan}

Untuk mengetahui pengaruh waktu pengocokan tepung biji salak yang menghasilkan rendemen glukomanan tertinggi diterapkan variasi waktu pengocokan. Rasio tepung biji salak : antisolvent isopropil alkohol $95 \%$ yang diterapkan adalah 1 : 13 (b/v) yang merupakan rasio terbaik dari hasil penelitian Ohtsuki (1968).

Rendemen glukomanan tertinggi yang diperoleh adalah $21,57 \%$ diperoleh pada waktu pengocokan 150 menit, sedangkan rendemen terendah adalah $15,26 \%$ pada waktu pengocokan 30 menit. 


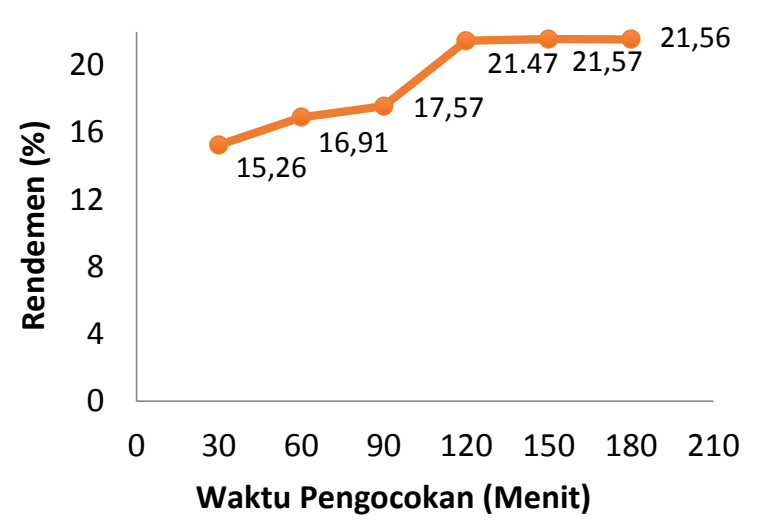

Gambar 1 Grafik hubungan waktu pengocokan terhadap rendemen glukomanan

Rendemen glukomanan biji salak mengalami peningkatan dari waktu pengocokan 30 menit hingga 120 menit (Gambar 1), hal ini menunjukkan bahwa semakin lama ekstraksi berlangsung, maka rendemen yang diperoleh akan semakin meningkat. Hal tersebut disebabkan karena semakin lama ekstraksi berlangsung, maka semakin banyak pula kontak antara tepung biji salak dengan pelarut, namun pada waktu pengocokan 120 menit sampai 180 menit cenderung stabil. Jika dibandingkan dengan beberapa penelitian tentang waktu ekstraksi glukomanan dilaporkan bahwa waktu ekstraksi terbaik pada glukomanan dari umbi iles-iles yaitu selama 3 jam (Fadilah, dkk, 2009). Selain itu Istianah, dkk. (2012) melaporkan bahwa waktu ekstraksi terbaik pada glukomanan dari lidah buaya yaitu 2 jam.

Hasil analisis sidik ragam menunjukkan bahwa waktu pengocokan berpengaruh nyata terhadap rendemen glukomanan yang dihasilkan. Berdasarkan hasil uji lanjut Duncan dengan taraf kepercayaan 95\% $(\alpha=0,05)$, diperoleh bahwa waktu 30, 60, dan 90 menit berbeda tidak nyata, tetapi berbeda nyata dengan waktu 120, 150, dan 180 menit. Dengan demikian waktu pengocokan 120 menit dapat direkomendasikan untuk diaplikasikan dalam ekstraksi glukomanan dari tepung biji salak.

\section{Rasio Terbaik Tepung Biji Salak : Anti- solvent Isopropil Alkohol 95\% Pada Ekstraksi Glukomanan}

Untuk mengetahui pengaruh rasio tepung biji salak terhadap anti-solvent isopropil alkohol yang menghasilkan rendemen glukomanan tertinggi diterapkan berbagai variasi volume antisolvent. Hasil yang diperoleh menunjukkan bahwa rendemen tertinggi adalah 40,19\% yang didapatkan pada perlakuan dengan rasio $1: 17$ (b/v), sedangkan rendemen terendah adalah $18,83 \%$ yang didapatkan pada perlakuan dengan rasio $1: 9(\mathrm{~b} / \mathrm{v})$.

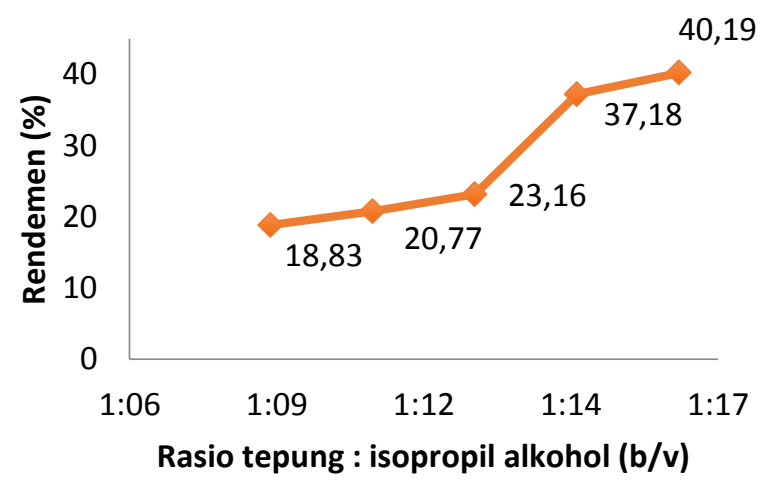

Gambar 2 Grafik hubungan rasio tepung biji salak : anti-solvent isopropil alkohol (b/v) terhadap rendemen glukomanan

Pada Gambar 2, memperlihatkan bahwa rendemen glukomanan tepung biji 
salak berkorelasi positif bertambahnya volume anti-solvent isopropil alkohol 95\% yang ditambahkan. Hal tersebut disebabkan karena semakin banyak antisolvent yang ditambahkan pada filtrat maka semakin banyak air yang akan ditarik oleh anti-solvet tersebut dari filtrat yang mengakibatkan glukomanan yang memiliki bobot molekul lebih besar akan mengendap.

Penggunaan isopropil alkohol sebagai anti-solvent ini lebih efisien dan menguntungkan jika dibandingkan dengan jenis alkohol lainnya seperti metanol dan etanol. Isopropil alkohol lebih bersifat nonpolar daripada metanol dan etanol jika dilihat dari nilai konstanta dielektiknya. Sifat lebih non-polar ini yang akan membuat kelarutan glukomanan terhadap pelarut menurun, karena molekul air telah tertarik oleh isopropil alkohol, dan akibatnya glukomanan yang berbobot molekul besar akan mengendap. Selain itu isopropil alkohol bersifat aman dan tidak toksik terhadap bahan pangan jika dibandingkan dengan metanol.

Berdasarkan hasil analisis sidik ragam menunjukkan bahwa rasio tepung biji salak : isopropil alkohol (b/v) berpengaruh nyata terhadap rendemen glukomanan yang dihasilkan. Dari hasil uji lanjut Duncan dengan taraf kepercayaan 95\% $(\alpha=0,05)$, diperoleh bahwa rasio 1 : 9 dan $1: 11$ berbeda tidak nyata dan rasio $1: 11$ dan $1: 13$ juga berbeda tidak nyata, sedangkan pada rasio $1: 15$ dan $1: 17$ berbeda nyata. Dengan demikian, rasio 1 :
17 (b/v) dapat direkomendasikan untuk diaplikasikan dalam ekstraksi glukomanan dari tepung biji salak.

Rendemen glukomanan dari hasil penelitian ini lebih tinggi dibandingkan dengan rendemen glukomanan pada umbi iles-iles dari hasil penelitian yang ada antara lain 24,90 \% (Pramathana, 2013), $38.17 \%$ (Dwiyono, 2014). Perbedaan rendemen glukomanan yang diperoleh disebabkan oleh perbedaan jenis tamanan. Selain itu, penggunaan antisolvent dan proses sentrifugasi diduga mampu menghasilkan glukomanan yang lebih murni dan meningkatkan jumlah rendemennya.

\section{Karakteristik Glukomanan}

\section{Kadar Air}

Umur simpan suatu bahan pangan dapat diperpanjang dengan menghilangkan sebagian kandungan air hingga mencapai kadar tertentu sehingga menghindari pertumbuhan mikroba, reaksi pencoklatan dan hidrolisis lemak. Menurut Fardiaz (1989), batas kadar air minimum dimana mikroorganisme masih dapat tumbuh adalah 14 - $15 \%$. Kadar air yang terlalu tinggi dapat menyebabkan penurunan mutu produk yang dihasilkan.

Berdasarkan hasil pengukuran kadar air pada penelitian diperoleh kadar air glukomanan adalah 11,18 \%. Kadar air hasil analisis tepung di atas cukup baik karena telah mencapai kisaran kadar air tepung yang aman yaitu kurang dari $14 \%$. Jika dibandingkan dengan kadar air pada 
penelitian sebelumnya, kadar air tersebut tidak jauh berbeda dibandingkan hasil penelitian Nurjanah (2010) yaitu 11,10\%.

\section{Kadar Abu}

Manfaat utama penentuan kadar abu suatu bahan pangan adalah untuk mengetahui banyaknya kandungan mineral yang terdapat dalam bahan (Sudarmadji, 1989).

Berdasarkan hasil analisis kadar abu pada tepung glukomanan biji salak, didapatkan kadar abu sebesar 1,2\%. Kadar abu pada tepung glukomanan biji salak ini telah memenuhi standar mutu yang ditetapkan oleh Asosiasi Konyaku Jepang (1976) yaitu kurang dari 3\%. Jika dibandingkan dengan hasil penelitian sebelumnya kadar abu glukomanan yang diekstrak dari umbi iles-iles lebih tinggi dibandingkan dari penelitian yang dilakukan, yaitu 3,33 \% (Nurjanah, 2010).

\section{Berat Molekul}

Penentuan berat molekul (BM) dari glukomanan dilakukan dengan metode kapiler atau Ostwald. Prinsip dari metode ini yaitu mengukur waktu yang dibutuhkan bagi cairan yang diukur untuk melewati dua tanda batas karena gaya gravitasi pada viskometer ostwald. Viskositas adalah ukuran hambatan suatu fluida untuk mengalir. Semakin besar viskositas, maka makin lambat aliran cairan. Perbandingan antara viskositas larutan polimer terhadap pelarut murni dapat digunakan untuk menentukan berat polimer.
Penentuan berat molekul glukomanan bertujuan untuk penggunaannya dalam industri baik makanan maupun yang lainnya. Polimer yang memiliki berat molekul besar diaplikasikan untuk bahan tambahan makanan, obat-obatan, dan bahan perekat. Sedangkan polimer yang memiliki bobot molekul yang lebih kecil memiliki aplikasi yang lebih luas contohnya sebagai antibakteri dan prebiotik.

Berdasarkan hasil penelitian diperoleh berat molekul glukomanan biji salak adalah $2,057 \times 10^{4} \mathrm{~g} / \mathrm{mol}$. Berat molekul glukomanan dari umbi porang hasil penelitian Teramoto dan Fuchigami (2000) adalah sekitar $1,0 \times 10^{4}-1,2 \times 10^{4}$ $\mathrm{g} / \mathrm{mol}$, sedangkan dari hasil penelitian Mei, dkk. (2012) yaitu sekitar $2,508 \times 10^{5} \mathrm{~g} / \mathrm{mol}$.

\section{Spektrum FTIR}

Identifikasi gugus fungsional glukomanan dilakukan dengan menggunakan spektrofotometer infra merah. Pada spektrum infra merah glukomanan, serapan vibrasi ulur gugus -OH terdapat pada bilangan gelombang $3431,00 \mathrm{~cm}^{-1}$. Data ini diperkuat dengan pernyataan Zhang, dkk., (2001) yang menyatakan bahwa spektra glukomannan didominasi oleh pita spektra yang berkaitan dengan vibrasi ulur gugus $-\mathrm{OH}$ dan air pada kisaran spektrum $3396 \mathrm{~cm}^{-1}$, data ini juga didukung hasil penelitian Irawan, dkk (2013) serapan ulur $-\mathrm{OH}$ terletak di daerah $3438,84 \mathrm{~cm}^{-1}$. Serapan pada bilangan gelombang $2924,15 \mathrm{~cm}^{-1}$ 
menunjukkan vibrasi ulur gugus gugus $\mathrm{C}-\mathrm{H}$ alkana $\left(-\mathrm{CH}_{3}\right.$ atau $\left.-\mathrm{CH}_{2}-\right)$. Xiao, dkk (1999) menyatakan bahwa puncak spektra gugus metil dari $-\mathrm{CH}$ berada pada spektrum $2920 \mathrm{~cm}^{-1}$.

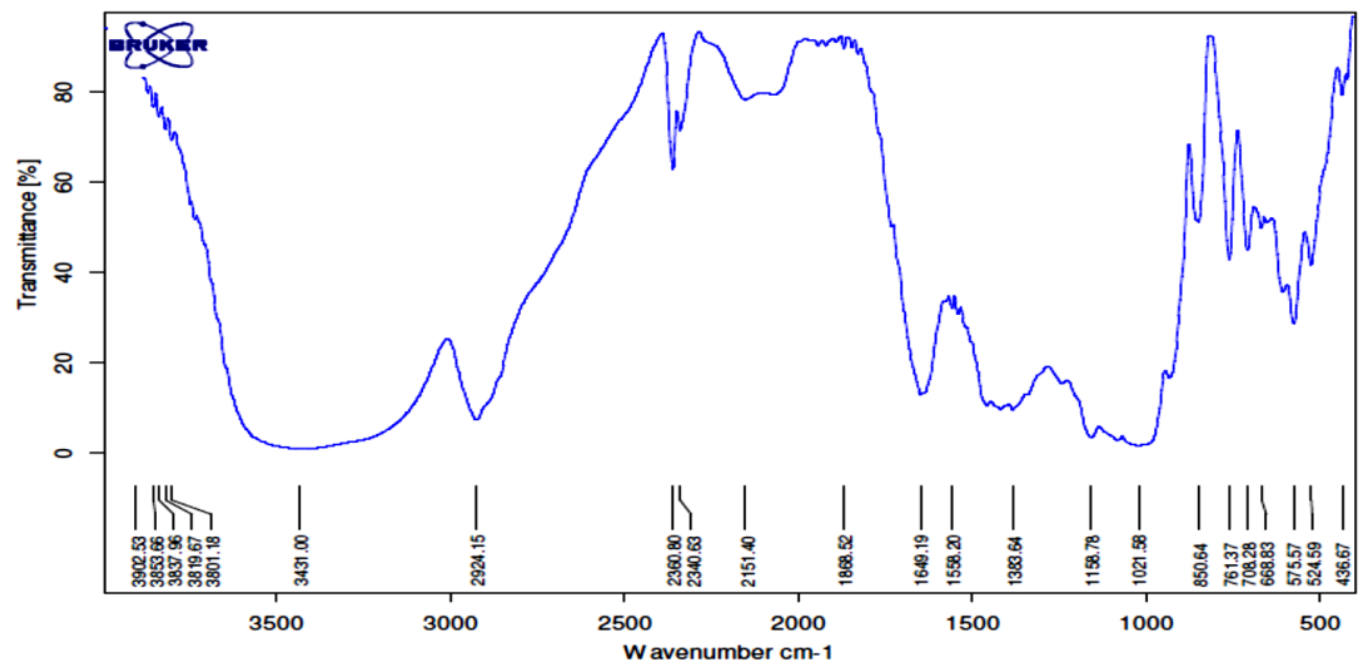

Gambar 3. Spektrum FTIR Glukomanan Biji Salak

Pita serapan pada bilangan gelombang 1649,19 $\mathrm{cm}^{-1}$ menunjukkan adanya gugus $\mathrm{C}=\mathrm{O}$, Xiao, dkk., (1999) menyatakan bahwa puncak serapan pita spektra pada gugus karbonil glukomannan yang ditambahkan akrilamida berada pada $1671 \mathrm{~cm}^{-1}$, Irawan, dkk (2013) menemukan pita serapan gugus $\mathrm{C}=\mathrm{O}$ pada bilangan gelombang $1647,10 \mathrm{~cm}^{-1}$. Puncak pada $1628 \mathrm{~cm}^{-1}$ disebabkan karbonil dari kelompok asetil (Zhang, dkk., 2001). Pita serapan pada bilangan gelombang $1021.58 \mathrm{~cm}^{-1}$ menunjukkan adanya gugus fungsi C-O-C dan pada pita serapan pada bilangan gelombang 850,65 $\mathrm{cm}^{-1}$ menunjukkan vibrasi tekukan gugus $-\mathrm{CH}$. Hua, dkk., (2004) menyatakan bahwa gugus manosa dan glukosa terlihat melalui kenampakan pita pada 814 dan $873 \mathrm{~cm}^{-1}$ yang berkaitan dengan vibrasi tekukan gugus $-\mathrm{CH}$.
Berdasarkan hasil penelitian dapat disimpulkan bahwa waktu pengocokan terbaik diperoleh pada 120 menit dengan rendemen glukomanan $21,47 \%$ dan rasio tepung biji salak : anti-solvent isopropil alkohol terbaik yaitu $1: 17$ (b/v) dengan rendemen glukomanan 40,19\%. Hasil karakterisasi terhadap glukomanan adalah kadar air 11,18\%, kadar abu 1,2\%, dan berat molekul 2,057 x $10^{4} \mathrm{~g} / \mathrm{mol}$.

\section{UCAPAN TERIMA KASIH}

Terima kasih kepada Pranata Laboratorium Jurusan Kimia FMIPA Universitas Tadulako yang telah membantu dalam pelaksanaan penelitian.

\section{DAFTAR PUSTAKA}

Akbar H., Supriyanto A., Haryani K. 2013. Karakterisasi Tepung Konjak dari Tanaman lles-lles (Amorphopallus Oncophyllus) di Daerah Gunung Kreo Semarang Jawa Tengah. 
Jurnal Teknologi Kimia dan Industri, 2 (4): 1-47.

Dwiyono K. 2014. Perbaikan Proses Pengolahan Umbi lles-lles (Amorphophallus muelleri Blume) Untuk Agroindustri Glukomanan. [Disertasi]. Bogor: Sekolah Pascasarjana IPB.

Fadilah, Distantina S., Prihani K., Wulan N. 2009. Koefisien transfer massa volumetris (Kca) pada ekstraksi glukomanan dari umbi iles-iles. Pemanfaatan Potensi Lokal Meunju Indonesia Produktif. Prosiding Simposium Nasional RAPI VIII; Surakarta, 17 Desember 2009. Surakarta: Fakultas Teknik UMS.

Fardiaz S. 1989. Mikrobiologi Pangan I. PAU Pangan Gizi. Bogor: Institut Pertanian Bogor.

Faridah A., Widjanarko SB., Sutrisno A, Susilo B. 2012. Optimasi Produksi Tepung Porang dari Chip Porang Secara Mekanis dengan Metode Permukaan Respons. Jurnal Teknik Industri. 13(2): 158-166.

Hua Y-fen, Zhang M, Fu C-xin, Chen, Zhui, Chan GYS. 2004. Structural Characterization of a 2-Oacetylglucomanan from Dendrobium officinale Stem. Carbohydrate Res. (339): 2219-2224.

Irawan SS., Widjanarko. 2013. Metilasi Pada Tepung Porang (Amorphophallus muelleri) Menggunakan Pereaksi Dimetil Sulfat Berbagai Variasi Konsentrasi. Jurnal Pangan dan Agroindustri, 1 (1): 148-156.

Istianah M., Mahadi S., Retnowati D. 2012. Isolasi manan dari lidah buaya (Aloe vera) dengan proses ektraksi sebagai bahan dasar pembuatan edible coating berbasis polisakarida. Jurnal Teknologi Kimia dan Industri, 1 (1): 396-400.

Koswara S. 2009. Modul Teknologi Pengolahan Umbi-Umbian, Bagian
2. Pengolahan Umbi Porang. Bogor: SEAFAST Center Research and Community Service Institution IPB.

Mei Xu., Dong-Sheng Li., Bin Li., Chao Wang., Yu-Peng Zhu., Wen-Ping Lv., Bi-Jun Xie. 2012. Comparative study on molecular weight of konjac glucomannan by gel permeation chromatography-laser light scattering-refractive index and laser light-scattering methods. Journal of Spectroscopy, 2013: 1-4.

Nugroho DA. 2014. Studi Potensi Biji Salak (Salacca edulis Reinw) Sebagai Sumber Alternatif Monosakarida Dengan Cara Hidrolisis Menggunakan Asam Sulfat. [Skripsi]. Yogyakarta: Fakultas Teknologi Pertanian Universitas Gadjahmada.

Nurjanah Z. 2010. Kajian Proses Pemurnian Tepung Glukomanan Dari Umbi lles-lles Kuning (Amorphophallus oncophyllus) Dengan Menggunakan Enzim $\alpha$ Amilase. [Skripsi]. Bogor: Fakultas Teknologi Pertanian Institut Pertanian Bogor.

Ohtsuki T. 1968. Studies on reserve carbohydrates of flour Amorphophallus species, with special reference to manan. Botanical Magazine Tokyo. (81): 119 $-126$.

Pramathana A. 2013. Karakteristik Tepung Porang (Amorphophallus oncophyllus) Dengan Variasi Perendaman Abu dan Garam Dapur Dalam Rangka Pengurangan Kandungan Asam Oksalat. [Skripsi]. Jember: Fakultas Teknologi Pertanian Universitas Jember.

Retnowati S, Kumoro C. 2012. Manan precipitation from aloe vera leaf pulp juice using methanol and isopropyl alcohol as anti-solvent: experimental and empirical modelling approach. Reaktor, 14 (1): 46-50 
Rohimi F., Ninghidayati S. 2013. Pengaruh Temperatur Ekstraksi Terhadap Kualiatas Tepung Glukomanan dari Tanaman Porang (Amorphopallus Muelleri Blume). [Skripsi]. Surabaya: Jurusan Teknik Kimia Institut Teknologi Surabaya.

Saputro E., Lefiyanti O., Mastuti E. 2014. Pemurnian tepung glukomanan dari umbi porang (Amorphopallus muelleri Blume) menggunakan proses ekstraksi/leaching dengan larutan etanol. Inovasi Keteknikan untuk Pembangunan Berkelanjutan. Prosiding Simposium Nasional RAPI XIII; Surakarta, 4 Desember 2014. Surakarta: Fakultas Teknik UMS. hIm K-7 - K-13.

Singh RB., Shelley. 2007. Polysaccharide structure of degraded glucomanan from Abrus precatorius Linn. Seeds. Journal of Environmental Biology. 28 (2): 461-464.

Sudarmadji S. 1989. Analisa Bahan Makanan dan Pertanian. Libert. Yogyakarta.

Supriyadi, Suhardi, Suzuki M., Yoshida K., Muto T., Fujita A., Watanabe N. 2002. Changes in The Volatile Compounds and in The Chemical and Physical Properties Of Snake Fruit (Salacca edulis Reinw) Cv. Pondoh during maturation. J Agric Food Chem, 50 (26): 7627-7633.

Syaefullah M. 1990. Studi Karakteristik Glukomanan dari Sumber "Indegenous" iles-iles (Amorphophallus oncophyllus) dengan Variasi Proses Pengeringan dan Dosis Perendaman. [Tesis]. Bogor: Fakultas Pascasarjana IPB.

Teramoto A., Fuchigami M. 2000. Changes in temperature, texture and structure of konnyaku (Konjac Glucomannan Gel) during highpressure-freezing. Journal of Food Science, 65 (3): 491 - 497
Whistler RL., Richards EL. 1970. Hemicelluloses, Dalam Pigman, W.D. The Carbohydrates, Chemistry and Biochemistry, 2nd ed. New York: Academic Press.

Widjanarko S., Megawati J. 2015. Analisis metode kalorimetri dan gravimetri pengukuran kadar glukomanan pada konjak (Amorphopallus Konjac). Jurnal Pangan dan Agroindustri, 3 (4): 1584-1588.

Wigoeno YA. 2013. Analisis kadar glukomanan pada umbi porang (Amorphophallus muelleri Blume) menggunakan refluks kondensor. Jurnal Biotropika, 1 (5): 191 - 195.

Xiao CB., Gao SJ., Li GR., Zhang QC. 1999. Preparation of konjac glucomannan and acrylamide grafted konjac glucomannan. J. Natl. Sci., (4): 459-462.

Yopi, Purnawan A., Thontowi A., Hermansyah H., Wijarnako A. 2006. Preparasi mannan dan mannanase kasar dari bungkil kelapa sawit. Jurnal Teknologi, (4): 312-319.

Zhang $H_{\text {., }}$ Yoshimura M., Nishinari K., Williams MAK., Foster TJ., Norton IT. 2001. Gelation behaviour of konjac glucomanan with different molecular weight. Biopolymers, (59): 38-50. 